\title{
Morphometric characterization of the pine processionary, Thaumetopoea pityocampa in the Tlemcen area, Algeria
}

\author{
Chahbar $M^{* 1}$, Kherroubi $M^{2}$, Boutchiche $\mathrm{F}^{3}$, Boutrigue $\mathbf{S}^{3}$, Gaouar S.B.S ${ }^{3}$ \\ ${ }^{1}$ : Laboratory of Agronomy and environment, Department of Biology, Faculty of Sciences and \\ Technology, University of Tissemsilt, Algeria \\ 2 : Laboratory of Ecobiology animals, Training School of Teachers, Vieux Kouba Algeria \\ ${ }^{3}$ Laboratory of Applied Genetics in Agronomy, Ecology and Public Health, University Abou Bekr \\ Belkaid, Tlemcen, Algeria
}

\section{*Corresponding author e-mail: chahbar_mohamed@yahoo.com}

Article history; Received: March 5th 2021;, Revised. May 3th 2021; Accepted June 10th 2021

\begin{abstract}
The pine processionary (Thaumetopoea pityocampa) is the most important defoliator of coniferous forest of the Mediterranean basin. The pine processionary also caused real public health problems. The urticat property is the origin of its health problems. It is still the subject of several studies to this day in order to develop friendly control strategies that respect the environment. The study carried out about the characterization of the pine processionary populations in two stations of pine forests located at the area of the Tlemcen. The caterpillars were collected in January 2016 in the Tlemcen region. Measurements were performed on L5 larvae and male and female nymphs. The statistical analyses were carried out using the SAS 9 software. The results obtained show that the females have an average length of $11.51 \pm 1.07 \mathrm{~mm}$ and an average width of $7.87 \pm 0.33 \mathrm{~mm}$. Males have an average length and width of $11.51 \pm 1.07 \mathrm{~mm}$ and $6.48 \pm 0.29 \mathrm{~mm}$, respectively. The length and width of the head capsule is $43.28 \pm 6.63 \mathrm{~mm}$ and $4.50 \pm 1.35 \mathrm{~mm}$ respectively. The GLM procedure of the SAS.9 software allowed us to observe that the Sebdou station is more attacked by this insect compared to the Ghazaouet station despite that there is a similarity between the biometric characters of the pine plants. Our statistical analyses have also shown that trees with the longest needles are the most resistant against insect attack.
\end{abstract}

Keywords: Thaumetopoea pityocampa, Pinus halepensis, Tlemcen, biometrics

\section{Introduction}

Algerian forest occupies 4.7 million hectares distributed in the northern part of the country (DGF, 2007). it is consists of a mixture of tree species, mainly the Aleppo pine, maritime pine, stone pine, cork oak, holm oak and Atlas cedar. These biotic communities are currently threatened by various species of defoliators and borers (Imbault et al., 2013; Rossi et al., 2016). The most spectacular defoliation caused by the processionary of softwood and hardwood (Rousselet et al., 2015). Adults in this group of social insect shave a very limited lifetime. The larvae known for their gregarious life style, their greed (Fraval, 2007) and their stinging properties pose many health problems even for humans and animals. With the known climate change, the infestations of this defoliator take a wider dimension recorded in her range and accentuated by the decline of her natural enemies (Van Dyck, 2012; Roques et al., 2015).

Extending the range of host species plays a very important role in the movements of the insect (Battisti et al., 2015). The temperature remains the determining factor in its distribution and the health of forest stands. Currently, infestations of this insect affect in southern Europe and northern Africa (FAO, 2010). In Algeria, two species Thaumetopeoa bonjeani Powel and Thaumetopoea pytiocampa Schiff are responsible for cedar defoliation (Bertella, 1987; Demolin And Martin, 1989). If the first is scarce and specific, the second is very cosmopolitan and causes significant damage to pines and cedars in the Mediterranean region. In this context, we studied the biometry of the pine processionary by the 
measurements of L5 larvae and the pupal stage, in order to have an idea about the diversity as well as the number of populations that exist and then to carry out an evaluation of the pine trees resistance against processionary caterpillar in the Tlemcen forest.

\section{Materials and methods}

\section{Study region}

After the prospecting in the semi-arid forests of Tlemcen, two sites were selected; the first is located $38 \mathrm{~km}$ south of Tlemcen in a reforestation in Sebdou and the second is a natural forest located in Ghazaouet, $72 \mathrm{~km}$ north-west of Tlemcen (Tient forest). 150 larvae per station were harvested in each of the two sites selected during the period of 05 and 07 March 2016 (figure 1).

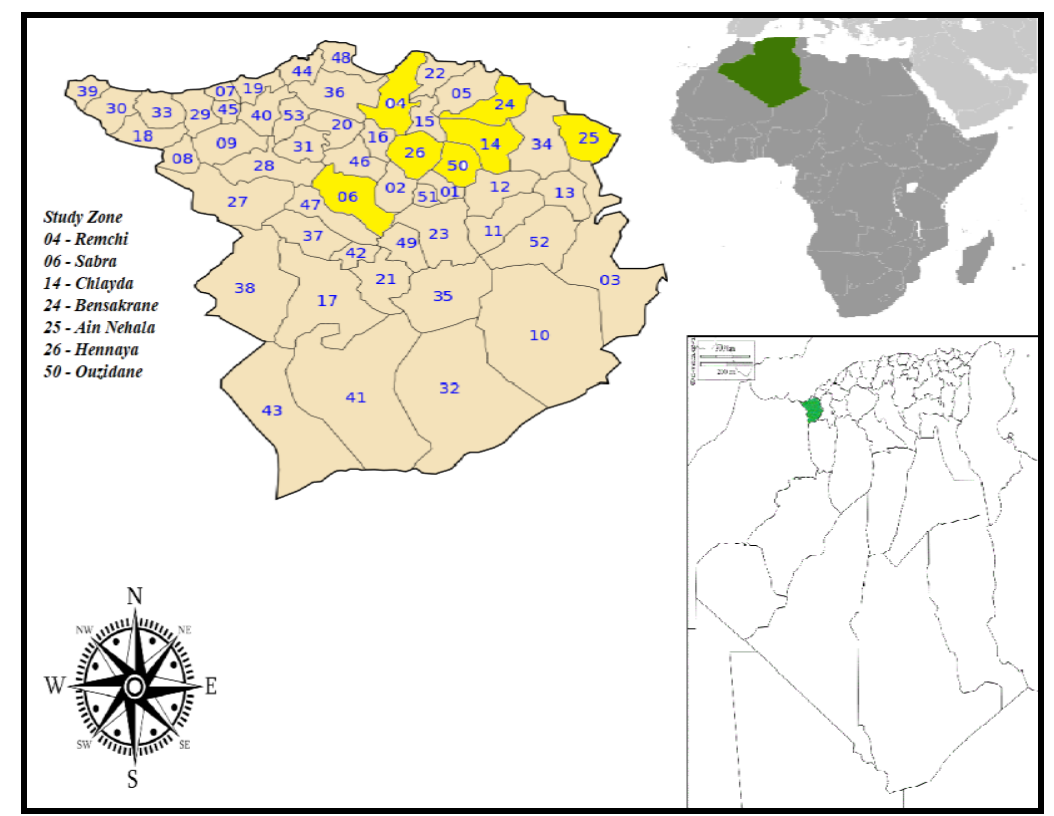

Figure 1 : Geographic location of Tlemcen

\section{Biological sampling}

We used a larval extraction system installed on the ground, under the nests of pine trees to catch the 4th and the 5th larval stage of processionary. The samples taken are measured using a caliper. The measurements concerned the total length of the L5 larvae and the width of its cephalic capsule, after storage in tubes with a soil base of $5 \mathrm{~cm}$ to ensure the chrysalis formation. The tubes were closed with mesh for ventilation and controlled daily. The transformation of larvae into nymphs and the release of parasitoids were noted. After pupation, the pupae were extracted from their cocoons. Finally, measurements of the length, width and weight were taken.

\section{Tree}

During the summer of January 2016, we selected 300 pine trees per station. Measurements were made on the length of the needles, stem and horn using a tape measure. The level of attack is estimated by counting the nests on the tree.

\section{Statistical analyzes}

All statistical analyzes were performed by software (SAS 9.0), the probability chosen is $5 \%$. The relation between the attacks of the processionary caterpillar and the length of the branches was studied based on a Simple Linear Regression by the execution of the procedure REGRESSION in the editor of the SAS 9. For the comparative study between the biometric characters of pine seedlings, the generalized linear model (GLM) was chosen. As for the Biometry of the 5th instar and the pupal stage, the descriptive analysis was performed using the Means procedure in the SAS editor in order to estimate the means and standard deviations. Sexual dimorphism was investigated by performing the GENMOD procedure. 


\section{Results and discussion}

\section{Relationship between Processionary Moth attacks and branch length}

The relationship between Processionary Moth attacks and twig length was investigated based on a simple linear regression by performing the REGRESSION procedure in the SAS editor 9 . The results show that there is a very weak negative correlation $(\mathrm{DF}=3 ; \mathrm{F}=1.34 ; \mathrm{p}=0.2618$; with a correlation coefficient $\mathrm{r}=0,6 \%$ ) between the length of the branches and the level attack of the processionary caterpillar (Figure 2).

The pine processionary attacks all species of pines in the Mediterranean region, as well as occasionally cedars. She nevertheless shows particular preferences when the female is in the presence of several species. Its feeding behavior allowed the establishment of its preferences for certain species whose order is as follows (Demolin, 1969c): - Austrian pine, - Corsican pine laricio, - Laricio pine, Maritime pine, - Pine Scots, - Aleppo pine, - Atlas cedar, - Lebanon cedar. Demolin (1969a) notes that this order is explained by the fact that the first selection criterion of female eggs mass is the diameter of the needles. Kherroubi et al. (2016) noted that there is a relationship between the lengths of needles and twigs and the number of eggs and that the correlation coefficients between these parameters are highly significant. As regards the diameters of the eggs mass, they are related to the diameters of the plant support (Demolin, 1969a). Montoya (1984) showed also that the host plant influences larval development.

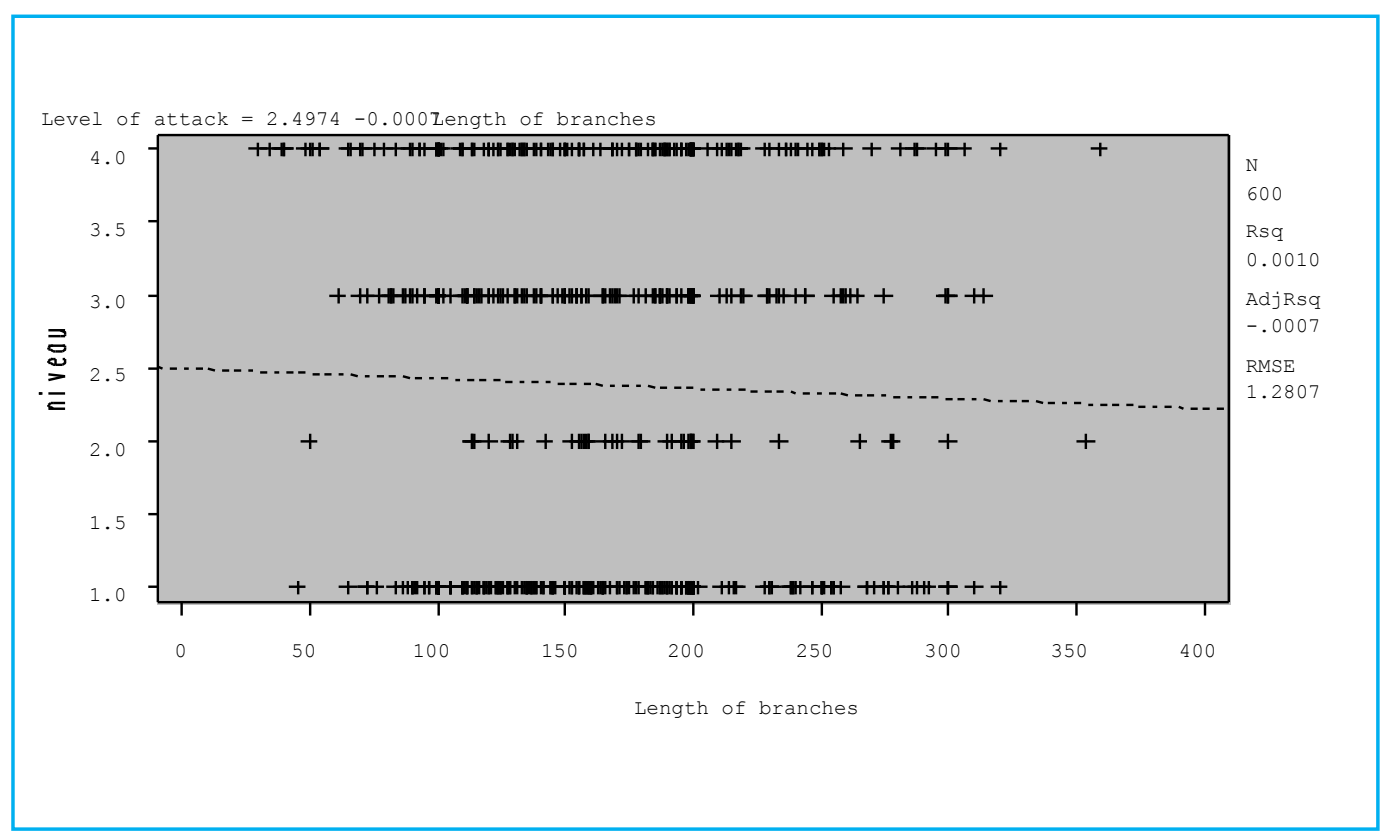

Figure 2: Relationship between the length of the branches and the level of attack of the processionary Comparative study between the biometric characteristics of pine trees

The average branch length was estimated to be $166.48 \mathrm{~cm}$ for all the pines studied at the two study stations. We find that there is a highly significant difference between the length of the branch among the trees $(\mathrm{DF}=29 ; \mathrm{F}=3.25 ; \mathrm{P}<.0001)$ and between the study stations $(\mathrm{DF}=1 ; \mathrm{F}=25,51 ; \mathrm{P}<.0001)$. However, the value of the coefficient of determination $(\mathrm{R}$ squared $=0.170860)$ indicates that this difference among the trees and between the study stations is not conditioned by the length of the branch. That can be explained by the difference in age between the plants of the pine. The needles average length is equal to $7.01 \mathrm{~cm}$. It was found that there is no significant difference in needle length among trees $(\mathrm{DF}=29 ; \mathrm{F}=0.91 ; \mathrm{P}=0.5963)$ and between different stations $(\mathrm{DF}=1 ; \mathrm{F}=0.76 ; \mathrm{P}=$ 0.3833). Therefore, the length of the needles is the same for the two study stations and between the different trees in the Tlemcen region. The lengths of the cones for all the trees studied averaged 7.32 $\mathrm{cm}$. Note that there is no significant difference in the length of the cone among the trees $(\mathrm{DF}=29 ; \mathrm{F}=$ 1.06; $\mathrm{P}=0.3880)$ and between the different stations $(\mathrm{DF}=1 ; \mathrm{F}=1.83 ; \mathrm{P}=0.1771)$. This can be 
explained by the fact that this trait depends on the plant species and is not conditioned by any other external factor including the environmental and health conditions of the plants.

\section{The processionary caterpillar attack level between trees and stations}

A highly significant difference in the attack level of Processionary Moth was found between trees (DF $=29 ; \mathrm{F}=13.69 ; \mathrm{P}<.0001)$ and stations $(\mathrm{DF}=1 ; \mathrm{F}=255.16 ; \mathrm{P}<.0001)$. This allows us to see that there is an influence of trees on the attack level of this insect $\left(\mathrm{R}^{2}=0.538229\right)$. Therefore, the attack level of the processionary caterpillar is influenced by the tree factor to more than $53 \%$. The outbreaks of the processionary caterpillar are temporary with significant defoliation in natural forests, but the most severe are observed in reforestation (Kherroubi et al., 2016; Zamoum, 2002) and as the forest of Ghazaouet is natural and the forest of Sebdou is considered a young reforestation, this was clearly shown in the statistical results.

\section{Biometrics of the $5^{\text {th }}$ instar L5 and the pupa of the processionary caterpillar}

The generalized linear model (GLM) by the GENMOD procedure of SAS 9 was used to compare the biometry of male and female nymphs (300 observations). This comparison was made considering the sex ratio as a fixed factor and the total length, maximum width and weight of the nymphs as variable factors (Table 1).

A highly significant difference was found between the total nymph length $(\mathrm{DF}=1 ; \mathrm{F}=529.06 ; \mathrm{P}$ $<0.0001$ ) among the two sexes with $\mathrm{R} 2$ estimated at $64 \%$. We also noticed a highly significant difference between the maximum width of the nymphs ( $\mathrm{DF}=1 ; \mathrm{F}=67.79 ; \mathrm{P}<0.0001)$ among the two sexes with $\mathrm{R}$ squared estimated at $18 \%$. The weight of the nymphs between the two sexes, also shows a highly significant difference ( $\mathrm{DF}=1 ; \mathrm{F}=142.09 ; \mathrm{P}<0.0001$ ) with $\mathrm{R}$ squared estimated at $32 \%$. The results of measurements of the length, width and weight of the pupae showed a significant difference between these measurements in the two sexes. This sexual dimorphism has also been observed in populations that evolve on pine species by other researchers (Flaherty et al., 2012). A great heterogeneity also characterizes the male and female pupae of the pine processionary.

Table 1: comparison of the length, width and weight of the nymphs between the two sexes.

\begin{tabular}{llllllllll}
\hline & R square & $\begin{array}{l}\text { Coeff } \\
\text { Var }\end{array}$ & $\begin{array}{l}\text { Racine } \\
\text { MSE }\end{array}$ & Average & DF & Type III SS & Mean square & F & Pr $>$ F \\
\hline length & 0.639689 & 9.420155 & 1.218968 & 12.94000 & 1 & 786.1268296 & 786.1268296 & 529.06 & $<.0001$ \\
width & 0.185326 & 21.24154 & 0.881524 & 4.150000 & 1 & 52.67883599 & 52.67883599 & 67.79 & $<.0001$ \\
weight & 0.322858 & 23.43110 & 0.084235 & 0.359500 & 1 & 1.00816546 & 1.00816546 & 142.09 & $<.0001$ \\
\hline
\end{tabular}

\section{Sex ratio}

The results of sexing the nymphs at the two study stations are shown in Figures 3 and 4. Analysis of the figures shows that the proportion of females is higher than those of males in the Gazaouet station (figure 3), on the other hand in the Sebdou region (figure 4) the males are more present than the females. The sex ratio was calculated from the sexing of 300 nymphs. The value of this ratio is 1.96 in the Sebdou station is in favor of the males. When the sex ratio is in favor of males, the potential of the Thaumetopoea pityocampa population is low (Ferracini et al., 2020; Questienne and Miermont, 1978). These results can be explained by the primordial action of climatic factors on the biology of the pine processionary, in particular that of the minimum temperatures in January and the annual sunstroke. Ferracini et al. (2020) has suggested over the years that the gradations of this pest were primarily linked to climatic factors. The aforementioned author notes that high or low temperatures can cause significant physiological disturbances, which can go as far as stopping feeding. The feeding being nocturnal, is conditioned by the succession of a temperature above $9^{\circ} \mathrm{C}$ in the nest during the day and an air temperature above $0{ }^{\circ} \mathrm{C}$ the following night. Insulation and the mass effect intervene to compensate for the drops in temperature and allow processionary larvae to evolve over the winter in areas with high sunlight. The processionary has two thermal thresholds, which directly affect the survival of its populations. In fact, temperatures above $32^{\circ} \mathrm{C}$ are extremely harmful for incubating eggs or for evolving caterpillars. They are most often the cause of physiological mortality. At temperatures below $-16^{\circ} \mathrm{C}$ the caterpillars die. As for the processions, they only take place when the 
temperature of the ground is between $10^{\circ} \mathrm{C}$ and $22^{\circ} \mathrm{C}$. At lower temperatures, the caterpillars remain clustered on the soil surface and blossoming at higher temperatures (DEMOLIN, 1969b).

Natural enemies are considered to be effective regulators of insect populations. During all stages of its development, the processionary moth is subject to attack by various species classified as predators, parasitoids and pathogens. Bacteria, Bacillus thuringiensis and viruses such as Smithiavirus pityocampae can also infect processionary larvae (De Boer and Harvey, 2020; Geri, 1980). Bacillus thuringiensis is the bacterium most widely used in biological control on the various caterpillars of Lepidoptera. The fungi are also used as Beauveria against various Lepidoptera and Coleoptera.

While at Ghazaouet station, the sex ratio is 0.86 in favor of females. When the sex ratio is in favor of females, the potential of the population of Thaumetopoea pityocampa is high (Demolin, 1970; Ferracini et al., 2020). The distance to be traveled between the mating site and the spawning site does not seem to be a limit on the choice of host. The female can indeed travel distances of several kilometers, which facilitates the rapid spread of the infestation (Mirchev et al., 2020).

In addition, the processions can travel up to 40 meters (Demolin, 1971). The actual evolution of the distribution area between 1969 and 1996 was studied by Demolin et al. (1996), which show an increase in the insect towards the north of France. This progression is due to global warming observed since the beginning of the 1970s in Northern Europe. This hypothesis is confirmed by Goussard et al. (1998) and Hódar et al. (2003), who note an elevation progression of the species. This species has been operating a gradual and continuous northward movement since the early 1990s, consistent with the observed increase in temperatures in winter (Rousselet et al., 2010). The disappearance of temperatures unfavorable to the development of the processionary favored its progression in latitude (towards the north of France) but also in altitude (in the Alps, the Pyrenees and the Massif Central). The speed of the insect's progress will depend on its natural ability to colonize areas with more favorable climates and on its adaptation to the changes created by humans.

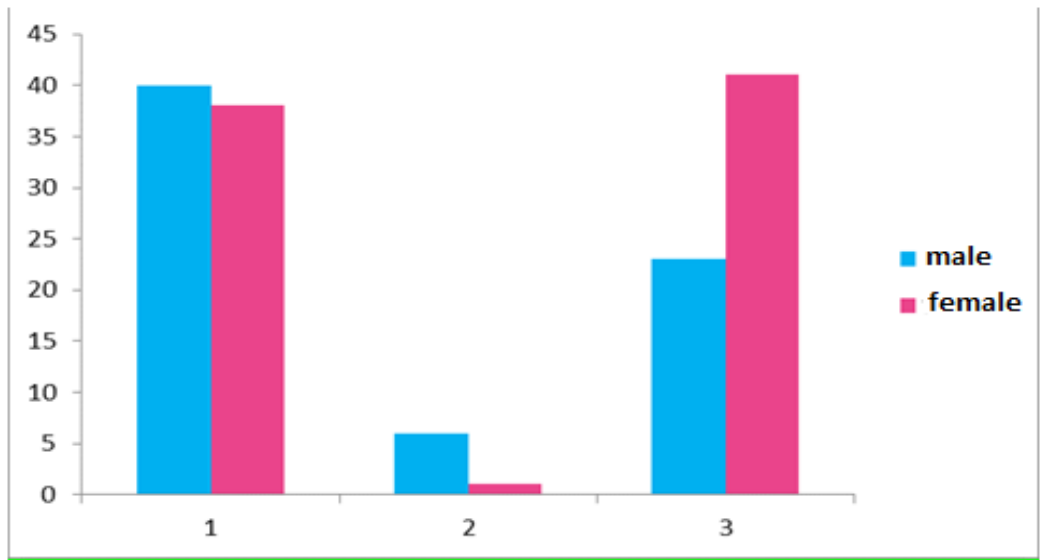

Figure 3: sex ratio in Ghazaouet station.

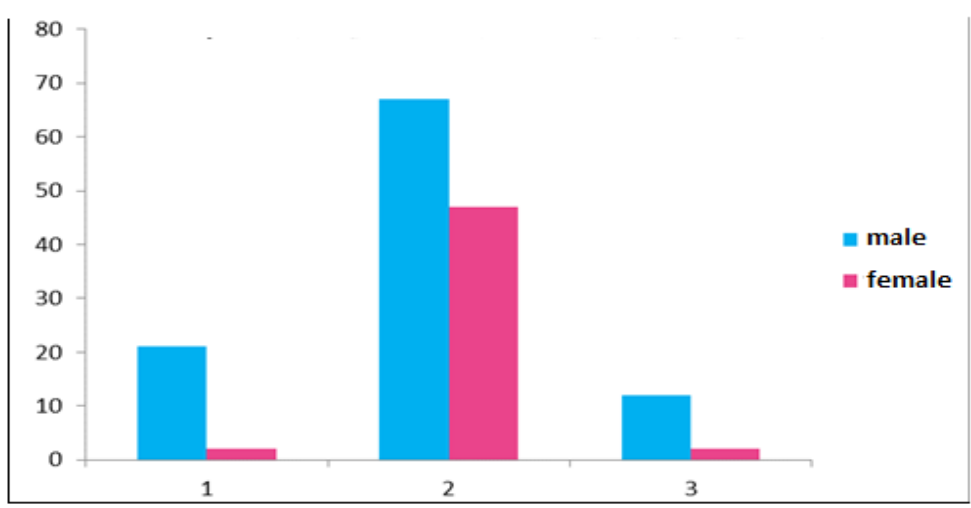

Figure 4: sex ratio in Sebdou station. 


\section{Conclusion :}

Due to the geographical spread of the pine processionary caterpillar, populations should be informed of the health risks, especially in newly colonized areas. The pine processionary infestations dynamics in the Tlemcen forests is particularly linked to its adaptation and its potential capacity to spread. These characteristics have provided populations with performance by enabling them to integrate all environmental factors into their development. The effects of climate change on the amplitude, frequency, and intensity of pine processionary outbreaks could have serious repercussions on the health of the Aleppo pine. The combined effect of stress, drought and defoliation severely limits tree growth. The climate is an important factor influencing the density of the Thaumetopoea stands which largely dominate in autumn and winter. The similarity of the composition of these stands between the two stations is high; the pine groves would attract the same entomological processions of the species Thaumetopoea by a similar floristic composition and the same environmental conditions, so the two stations are classified in the semi-arid bioclimatic stage. The work applied to the measurements of length, width and weight of the pupae revealed a great heterogeneity also characterizes the male and female pupae of the pine processionary.

\section{References}

Battisti AM. Avcı DN. Avtzis ML. Jamaa B. Berardi L. Berretima W. Hódar JA 2015. Natural history of the processionary moths (Thaumetopoea spp.): new insights in relation to climate change. In Processionary moths and climate change: An update, Springer Netherlands, pp: 15-79.

Bertella N 1987. Bioécologie de Thaumetopoea pityocampa Schiff. (Lepidoptera, Thaumetopoeidae) dans quelques régions d'Algérie. Thèse magister Sci.Agr., Institut National Agronomique ElHarrach-Algérie, 110.

De Boer JG. Harvey JA 2020. Range-expansion in processionary moths and biological control. Insects, 11(5), 267p.

Démolin G 1969a. Comportement des adultes de Thaumetopoea pityocampa Schiff. Dispersion spatiale, importance écologique. Ann. Sci. Forest. 26(1) : 81-102.

Démolin G 1969b. Bioecologica de la processionnariadelpino, Thaumetopoeapityocampa. Incidencia de losfactoresclimaticos. Bol. Serv. Plagas Forest. 23 : 9-24.

Démolin G 1969c. La processionnaire du pin. Note d'information sur la biologie et sur les techniques de lutte.

Démolin G 1970. Programa ecologico internacional sobre la Procesionaria del pino. Bol. Serv. Plagas Forest. $13: 111-117$.

Démolin G 1971. Incidences de quelques facteurs agissant sur le comportement social des chenilles de Thaumetopoea pityocampa Schiff. (Lepidoptera) pendant la période des processions de nymphose - Répercussionssur l'efficacité des parasites. Ann. Zool. - Écol. Anim. Hors série : 33-56.

Demolin G. Martin JC 1989. Essais d'efficacité du Foray $48 B$ sur la chenille processionnaire du pin, Thaumetopoea pityocampa Schiff.au troisième stade larvaire de son développement. Incidence de l'action simultanée de Xanthandrus comtus Harr. (Diptera, Syrphidae).C.R.interne, Inst.Nat. de la Rech.Agr, (Avignon), $12 \mathrm{p}$.

Demolin G. Abgrall JF. Bouhot-Delduc L 1996. Evolution de l'aire de la processionnaire du pin en France. Les cahiers du DSF 1-1996 (La Santé des Forêts - 1995), pp :26-28.

Demolin G. Rive JL 1968. La processionnaire du pin en Tunisie.Les Annales de l'INRF Tunisie, $1(1): 1-19$.

DGF (Directorate General of the forests). 2007. Politique forestière national et stratégie d'aménagement et de développement durable des resources forestières et alfatières. Directorate General of the forests, Algeria.

FAO 2010. Evaluation des ressources forestièrs mondiales, main report. Ed. the United Nations Organization for Food and Agriculture, Rome, pp: 53-114.

Ferracini C. Saitta V. Pogolotti C. Rollet I. Vertui F. Dovigo L 2020. Monitoring and Management of the Pine Processionary Moth in the North-Western Italian Alps. Forests, 11(12), 1253p.

Flaherty L. Régniere J. \& Sweeney J. 2012. Number of instars and sexual dimorphism of Tetropium fuscum (Coleoptera: Cerambycidae) larvae determined by maximum likelihood. The Canadian Entomologist, 144(5): 720-726. 
Fraval A 2007. Les Processionnaires - 1st part, The currant clearwing moth. Insects $35 n^{\circ}$ 147(4): 3539.

Geri C 1980. Application des méthodes d'études demecologiques aux insectes défoliateurs forestiers. Cas de Diprion pini L. (Hymenoptère, Diprionidae). Dynamique des populations de la processionnaire du pin Thaumetopoea pityocampa Schiff. (Lepidoptère, Thaumetopoeidae) dans lîle de Corse. Thèse doct.Etat, Orsey, Université Paris-Sud, 260p.

Goussard F. Saintonge FX. Geri C. Auger-Rozenberg MA. Pasquier BF. Rousselet J 1998. Increasing risk of damage by the pine processionary Thaumetopoea pityocampa Denis \& Schiff. in the Central Region following climatic change. Actes de la IV Conference Internationale Francophone d'Entomologie, Saint Malo, France, 5-9 juillet 1998, 35, 341-343.

Hódar JA. Castro J. Zamora R 2003. Pine processionary caterpillar Thaumetopoea pityocampa as a new threat for relict Mediterranean Scots pine forests under climatic warming. Biol. Cons. 110 : 123-129.

Imbault VJ. Garcia T. Lamant C. Robinet A. Roques A. Dowkiw Rousselet J. 2013. Inventaire des arbres-hôtes de la processionnaire du pin à l'interface ville-forêt-champs. In 3. AFPP. Conference Maintenance of Green Areas, Gardens, Lawns, Forestry, Aquatic Areas and Other Areas Non Agricultural; $\mathrm{p} 1$.

Kherroubi M. Mouhouche F. Gahdab C 2016. Importance of embryonic antagonists in regulating populations of processionary Thaumetopoea pityocampa (Denis \& Schiffermuller, 1775) Schiff in some Algerian cedar forests. Advances in Environmental Biology, 10(10): 20-29.

Mirchev P. Georgiev G. Zaemdzhikova G. Matova M 2020. Survival of the pine processionary moth at the egg stage in the summer and winter phenological forms in Bulgaria. Nauka za Gorata, 56(2): 21-30.

Montoya R. 1984. type of trap to catch males of the pineprocessionary. Boletin de la Estacion Central de Ecologia, 13 : 99- 103.

Questienne P. Miermont Y 1978. Contribution à la connaissance Thaumetopoea pityocampa Schiff. Etude de la chenille processionnaire du pin et du cèdre au Maroc. Ann. Rev. For. Maroc, Mai 1978. Pp :151-233.

Roques AJ. Rousselet M. Avcı D.N. Avtzis A. Basso A. Battisti AM. Branco M 2015. Climate warming and past and present distribution of the processionary moths (Thaumetopoea spp.) in Europe, Asia Minor and North Africa. In Processionary Moths and Climate Change: An Update, Springer Netherlands, pp: 81-161.

Rossi JP. Imbault VJ. Lamant C. Rousselet J. 2016. A citywide survey of the pine processionary moth Thaumetopoea pityocampa spatial distribution in Orléans (France). Urban Forestry \& Urban Greening, 20:71-80.

Rousselet J 2011. La chenille processionnaire du pin, Thaumetopoeapityocamparavageur forestier à lanuisance urbaine. Centre de recherche d'Orléans. INRA, 2p.

Rousselet J. Zhao R. Argal D. Simonato M. Battisti A. Roques A. Kerdelhue C 2010. The role of topography in structuring the demographic history of the pine processionar moth Thaumetopoea pityocampa (Lepidoptera Notodontidae). Journal of Biogeography, 37, 1478-1490.

Rousselet J. Imbault V. Lamant T. Gutleben C. Pieron S. Guérin M. Rossi JP. 2015. Influence du contexte paysager sur les attaques de processionnaire du pin en ville. Quelles perspectives de méthodes de lutte alternatives ? In 5. International Conference on Plant Protection, AFPP French Association of Alternative Methods of Plant Protection, pp: 214.

Van Dyck H 2012. Dispersal under global change the case of the Pine processionary moth and other insects. Dispersal Ecology and Evolution, 357p.

Zamoum M 2002. Quelques éléments pour la préservation de la santé des forêts en Algérie. Revue de la forêt algérienne, $\mathrm{n}^{\circ} 4$, juil .2002,pp : 4-7. 